\title{
THE IMPACT OF PEDAGOGICAL SUPPORT PROGRAM ON COPING STRATEGIES, ACADEMIC ACHIEVEMENT AND STRESS LEVEL IN ADOLESCENCE
}

\author{
Jūlija Maslova \\ Latvian Maritime Academy
}

\begin{abstract}
The article analyses development of coping strategies and coping resources using in adolescence. Adolescents are often not able to cope with stressful situations because their coping strategies still forming, that leads to academic performance reduction. Therefore, a pedagogical support program for developing coping strategies in adolescents is crucial, and it was elaborated and approved as a formative experiment method. Results revealed that after the implementation of pedagogical support program in the experimental group there were identified effective coping strategies. Also, it was observed that the academic achievement level increased and the stress level decreased in the experimental group.
\end{abstract}

Keywords: coping strategies; stress; academic achievement; adolescence; pedagogical support program

\section{Introduction}

Stress has become a customary feature of our daily life, but consequences of it may be very serious. Results of the international students' subjective health and psychological well-being study showed that the adolescent population of Latvia possesses psychological lability symptoms (irritability, bad mood, nervousness and depression) and different types of pain, which may indicate body overload and stress (Velika, et al., 2008). High level of stress can cause both emotional and health problems, and it has also a negative impact on students' academic achievements (Rafidan et al., 2009; Yusoff, et al., 2011). Mainly adolescents' inability to cope effectively with stress situations leads to such negative consequences. It is connected with the fact that coping behaviour which can help in dealing with difficulties and stress situations in adolescence is not formed yet. Currently psychologists are the ones who deal with coping strategies development in adolescents. However, teachers do not have psychological-pedagogical tools for it, but exactly they are the first who face problems caused by inability of adolescents to cope effectively with stress situations. Therefore, the author of the study has elaborated psychologicalpedagogical program for the teachers as an aid to develop coping strategies, optimize stress level and improve academic achievements of students within the pedagogical process. Elaboration of the psychological-pedagogical program was 
grounded on a presumption that coping strategies are being developed on the basis of the most important in adolescence coping resources of an individual and the environment (Малкина-Пых, 2005). The most significant personality resource helping to develop effective coping strategies is divergent thinking, which allows finding several solutions to the problem. In stress situations characterized by uncertainty and lack of information, exactly divergent thinking helps finding effective ways of problem solution (Грецов, 2012). One more important personality resource allowing effective coping with stress situations is a psychological competence in stress area and coping with it, possessed by teachers, students and their parents. With regard to the environmental coping resources allowing adolescents to cope effectively with difficulties and stress situations, a support from the side of teachers and parents is important. Thus, taking into consideration the most important personality and environmental coping resources for adolescents, such as divergent thinking, psychological competence and social support, the author has elaborated and approbated pedagogical support program which provides teachers with methods necessary to develop coping strategies and optimize students' stress level within the pedagogical process.

Hypothesis of the research - the pedagogical support program allows teachers to develop effective coping strategies, improve academic achievement and reduce stress level in adolescence in the pedagogical process.

Research aim: to approve the pedagogical support program for development of coping strategies among adolescents in the pedagogical process.

Research methods: analysis of scientific literature, formative experiment, questionary survey, statistical analysis of research data.

\section{Theoretical basis of the study}

Stress is caused by discrepancies between actual possibilities of a personality and objective requirements; it occurs in cases an individual is being asked to do more than he/ she can and assesses these discrepancies as a load or depletion of his/ her resources and exposure of his/ her well-being to danger (Lazarus \& Folkman, 1984). According to H. Selye (Selje, 2012) stress model, stress might not be only negative. When the available human resources meet the set requirements, a person is experiencing positive stress - eustress. Eustress occurs when a complex task is being performed, and it is accompanied by confidence in achieving successful result. Such stress might be useful. Therefore, an optimal level of stress can enhance learning ability (Kaplan \& Sadock, 2000). Negative stress or distress occurs when demands exceed available resources. It can cause problems of such cognitive functions as memory and attention, as well as incite negative emotional and behavioural 
reactions alongside with physical and mental health problems in adolescents (Frydenberg, 1997; Laio, Li \& Yi, 2007; Rutka, 2012). Stress reduces also learning effectiveness (Kaplan \& Sadock, 2000). A review of research works indicates that high level of stress leads to reduction of academic achievement of students (Rafidah et al., 2009; Yusoff et al., 2011). In order to reduce negative impacts of stress on their well-being, adolescents use coping strategies which tend to become conscious behaviour.

Coping strategies are defined as deliberate efforts based on certain activities with an aim to regulate subject's emotional and intellectual tension and achieve an optimal psychological adaptation to external conditions (Krukova, 2008, 2010). Lazarus and Folkman (1984) distinguished between two types of coping strategies: problem-focused and emotion-focused. Problem-focused coping strategies tend to be employed when an individual has determined that a stressful, challenging or threatening situation is amenable to change. When an individual experiencing stress, perceives the stressful situation to be outside of his/ her control, emotion-focused coping strategies may be employed (Lazarus \& Folkman, 1984). It was discovered that problem-focused coping strategies possess positive correlation with adaptation and health issues, but emotion-focused strategies, on the contrary, play negative role and intensify stress, as they do not solve a situation that occurred (Рассказова \& Гордеева, 2011).

Coping strategies are distinguished into two groups also according to the criterion of success (successfulness) in overcoming stressful situation (Малкина-Пых, 2005). The first group includes coping strategies helping to solve a problem and dealing with difficulties and stressful situation. Various terms are being used to name this particular group of coping strategies: effective, productive or constructive. In this study a term "effective coping strategies" will be used, as "effective" means something providing expected results and being efficient (Latviešu valodas skaidrojošā vārdnīca, 1987, 205), and it is the most appropriate within the meaning of coping strategies concept. The second group includes ineffective strategies that impede coping with difficulties and stress situations (Малкина-Пых, 2005). Therefore, the problemfocused coping strategies are associated with high operational efficiency and assessed subjectively as more effective than the emotion-focused coping strategies (Lazarus \& Folkman, 1984). Results of relevant studies show that adolescents who use such effective coping strategies as problem solving, working hard and achieving, focusing on positive aspects and seeking for social support are able to deal with difficulties and stressful situation in an adaptive manner, and they have higher academic achievement. On their turn, adolescents who apply such ineffective coping strategies as ignoring problem, suppressing tension, avoiding action and using aggressive behaviour have lower academic 
achievement (Barber \& Janet, 2010; Campbell, 2008; Choi \& Abbott, 2007; Hofer, 2007; Marcos \& Tillema, 2006; Niff \& Hsieh, 2005; Tucker, 2008; Veisson \& Leino, 2004).

Results of the study proves that adolescents health, well-being and academic achievement depend on what type of effective or ineffective coping strategies they use. Therefore, it is crucial to help in developing effective coping strategies exactly during adolescence period, when active formation of those strategies takes place (Frydenberg, 1997). Coping strategies can be developed with the help of personality and environment coping resources (Малкина-Пых, 2005). A term "coping resources" includes those personality and social environment factors that are available in a potential condition and in case of necessity could be used intentionally by a person to cope with stress or complicated life situation. It is also important that effectiveness of coping behaviour is tightly connected with an amount, character and availability degree of existing resources. Internal locus of control, self-efficiency hardiness, creativity, and other abilities and skills of a person are related to the personal resources. However, emotional support and assistance from friends and family refer to social environment resources.

While developing effective coping strategies within the pedagogical process, it is necessary to take into consideration not only educational environment, but also personal coping resources of adolescents. The most important environment coping resource is a social support (Frydenberg, 1997, 2002). Adolescents in complicated, problematic and stressful situations tend to seek for help and support among friends, classmates, parents and teachers. E. Frydenberg believes that referring to others for support is an effective way to cope with difficult and stressful situation. In accordance with research works, students who were supported by parents in complicated and stressful situations possess higher academic achievement than students who did not receive parental support (Rafidah et al., 2009; Smith \& Renk, 2007; Yusoff et al., 2011).

One of the main types of social support in pedagogical environment is a pedagogical support (Останина, 2009). Idea of the latter originates from S.A. Amonashvili's "pedagogy of cooperation". The pedagogical support is a preventive and operational assistance to adolescents in solving situations related to their individual problems which are connected with physical and psychical health, social and economic status, successful learning, accepting school regulations, effective work and interpersonal communication, as well as with life, professional and ethical choices (self-determination) (Газман, 1995). An aim of the pedagogical support is to develop subject position of an adolescent in such a way that at the moment a problem situation is faced, he/ she assesses it as an obstacle and feels a necessity to solve this problem. Subject position is characterized as a capacity of independent choice, as well as an existence of will 
and activity that has to be planned and realized. In such a way teachers realizing pedagogical support create conditions where a student becomes a subject of his/ her own life activity and forms effective coping strategies that allow coping with problems and stress situations.

Psychological competence and divergent thinking are the most important personality coping resources which allow developing effective coping strategies among adolescents within the pedagogical process.

Psychological competence is ability and skills of a personality to overcome routine problems effectively, maintain well-being and demonstrate adaptive and positive behavior in cooperation with other people and their cultural environment (Rutka, 2012, 75). Psychological competence in the field of stress and coping is a significant personal coping resource for developing effective coping strategies among teachers, students and parents of adolescents.

Psychological competence consists of psychology knowledge, divergent thinking, decision-making skills, self-control skills, emotional self-regulation skills, communication techniques application skills, responsibility and moral development (Rutka, 2012).

Different methods of psychological competence development can be used in the pedagogical process such as developmental tasks and games, psychological training, conducting classes based on stress and coping issue, learning relaxation techniques, interpreting stories and proverbs, analyzing problem situations, as well as analyzing positive examples of problems resolution.

Divergent thinking as a personal coping resource is a method of creative thinking, which is oriented on various ways of problem solving and leads to different and unexpected solutions and results. Divergent thinking is used for solving problems and tasks, in order to find several solutions for the same problem. Convergent thinking is directed towards the only one, single and correct result in accordance with the requirements of a particular situation (Guilford, 1985). However, despite differences, both ways of thinking divergent and convergent, are aspects of creative thinking (Fasko, 2001).

A. Grecov (2012) believes that divergent thinking is effective in situations when there's lack of exhaustive information, absence of strict rules and the perspective of the further scenario is not clear as these situations are the most stressful for the adolescents due to their ambiguity, informational shortage and the difficulty in finding the way out. However, as the resultsof the surveys/researches show, adolescents with a higher level of divergent thinking are able to find several solutions of solving the problem and choose the most effective coping strategy (Колиенко, 2008, Останина, 2009). 
Thus the following conclusion could be drawn: divergent thinking is an important coping resource in adolescense, and it is necessary to develop it during the pedagogical process.

Researches of correlation between divergent thinking and academic performance have shown contradictory results. For instance in several studies, a positive correlation between divergent thinking and academic performance was found. But in other studies, on the contrary, the correlation was not found, particularly in groups of students with very high level of divergent thinking (Ильин, 2012).

Druzhinin writes that academic achievements of gifted children are higher than of the ones who are not so quick in studying. However, among the exceptional learners there can also be found the ones with underachievement. Therefore the results of the researches show that the convergent and divergent thinking are both important for education (Ильин, 2012).

In such a way divergent thinking as a coping resource is a part of a broader coping resource - psychological competence. In its turn, development of psychological competence and divergent thinking is a part of pedagogical support aimed at development of effective coping strategies among adolescents within the pedagogical process.

Taking into account the results of theoretical and empirical researches, the pedagogical support program for the development of effective coping strategies among adolescents during the pedagogical process was elaborated. In these program frameworks, effective coping strategies in adolescence period are developed on the basis of such coping resources as pedagogical support, psychological competence and divergent thinking. This pedagogical support program was abundantly described by the author in the previous study (Maslova, 2016).

\section{Materials and methods}

The method used for development of coping strategies is formative experiment which consists of three stages:

Stage 1 - the research of coping strategies, academic achievements and stress level within the control and experimental groups.

Stage 2 - a 3-part implementation of pedagogical support program for students in the experimental group: a) the development of teacher's psychological competence, b) the development of students' divergent thinking and psychological competence, c) work with parents.

Stage 3 - the research of coping strategies, academic achievements and stress level after the implementation of pedagogical support program within the control group and the experimental group (Maslova, 2016). 
Participants: 57 high school students (17-19 years old), divided into two groups: control group -29 students, experimental group -28 students.

\section{Measures}

The Strategic Approach to Coping Scale (SACS) (Hobfoll, Dunahoo, Monnier, 1998) was developed by Stevan E. Hobfoll in 1998. Russian version of the test (Водопьянова, 2009) adopted by the author of current study. Each of the subscales show adequate psychometric properties, demonstrating internal reliability coefficients ranging from $\alpha=0,51$ to $\alpha=0,89$ ( $M=0,67 ; \mathrm{SD}=0,13)$. Minimum acceptable alpha coefficient in the scales that measure coping strategies is 0.65 (Крюкова, 2010, 18). Thus the adapted questionnaire can be considered acceptable for applications in the current study.

The SACS includes: (a) a prosocial-antisocial dimension which depicts the degree to which individuals are active in terms of their social interactions, while seeking their goal; (b) a passive-active dimension that depicts the efforts to solve problems versus ways to avoid them; (c) a direct-indirect dimension that depicts the efforts to address the problem directly in contrast to solving the problem by working around people's back.

The SACS has 52 items which are distributed to 9 subscales: assertive action, avoidant action, indirect action, seeking social support, social joining, cautious action, antisocial action, aggressive action, and instinctive action. Each item can be rated on a 5-point Lickert scale, ranging from 1 (not at all what I would do) to 5 (very much what I would do). In the SACS adapted by Vodopyanova also obtained index of effectiveness, which showed the effectiveness of coping behavior in a stressful situation. Effectiveness index level can be low, medium and high.

All these scales are self-report, easy to administer instruments that can be completed individually or in groups. The SACS produces 9 scores for each subscale, ranging from 4 to 45 .

Adolescent's Stress Survey (ASS) was developed by the author of current study. ASS has 25 items which discribe emotional states and behavier rections, related to stress. Each item can be rated on a 5-point Lickert scale. Reliability coefficient of survey is 0,85 .

To define the academic achievements of the students the Great Point Averages (GPA's) were obtained by the researcher in the current study.

The fact that students' aptitude for both human or exact sciences can prevail and affect their GPAs was also taken into account. For this reason the GPAs in both human and exact subjects were considered. 
Jülija Maslova. The Impact of Pedagogical Support Program on Coping Strategies, Academic Achievement and Stress Level in Adolescence

\section{Results and discussion}

Due to the fact that there is a compliance with normal distribution in the experimental and control samples, T-test was calculated. After implementation of the pedagogic support program, T-test was calculated to clarify, whether any changes in development of coping strategies, academic achievement and stress level in the experimental group took place.

Table 1 indicates that there is statistically significant difference between the level of stress before and after implementation of the pedagogical support program in the experimental group, but no difference in the level of stress was found in the control group at 0,05 level of significance. Comparing means and standard deviations, it is obvious that the level of stress has decreased after implementation of the pedagogical support program in the experimental.

Table 1 Results on the differences in the stress level before and after implementation of the pedagogical support program in the experimental and control groups

\begin{tabular}{|c|c|c|c|c|c|c|}
\hline \multirow{2}{*}{ Groups } & \multicolumn{7}{|c|}{ Measurements } & \multirow{2}{*}{ p } \\
\cline { 2 - 7 } & \multicolumn{2}{|c|}{$\begin{array}{c}\text { Measurement } \\
\text { before the } \\
\text { experiment }\end{array}$} & \multicolumn{2}{|c|}{$\begin{array}{c}\text { Measurement } \\
\text { after the } \\
\text { experiment }\end{array}$} & T & \\
\cline { 2 - 7 } & M & SD & M & SD & &, 021 \\
\hline Experimental group & 48,428 & 7,485 & 44,035 & 6,286 & $-2,378^{*}$ &, 484 \\
\hline Control group & 48,344 & 8,125 & 46,827 & 8,276 &,- 704 & \\
\hline
\end{tabular}

* T-test score is significant at the $p<0.5$ level (2-tailed)

Table 2 shows statistically significant difference in the level of stress between the experimental group and the control group after implementation of the pedagogical support program. The students in the experimental group had lower levels of stress than the students from the experimental group. The results indicate that application of pedagogical support program allowed reducing the level of stress in the experimental group.

Table 2 Results on the differences in the stress level between the experimental group and the control group after implementation of the pedagogical support program

\begin{tabular}{|c|c|c|c|c|c|}
\hline \multicolumn{2}{|c|}{ Experimental group } & \multicolumn{2}{c|}{ Control group } & \multirow{2}{*}{ T } & \multirow{2}{*}{ p } \\
\hline $\mathbf{M}$ & SD & M & SD & &, 004 \\
\hline 16,000 & 4,489 & 18,036 & 2,318 & $-2,995^{*}$ &, \\
\hline
\end{tabular}

$* T$-test score is significant at the $p<0.5$ level (2-tailed)

Table 3 indicates that there are statistically significant differences between levels of six coping strategies before and after implementation of the 
pedagogical support program in the experimental group with significance level lower than $0.05(\mathrm{p}<0.05)$. Comparing means and standard deviations, it is obvious that the level of effective coping - active and pro-social coping strategies such as social joining and seeking for social support has increased. Also index of effectiveness, which showed the effectiveness of coping behavior in a stressful situation has increased. However, level of ineffective, passive coping strategies such as cautious action, avoidant action and antisocial coping strategy - aggressive action has decreased.

The results suggest that adolescents have started coping with stress situations and difficulties more effectively putting efforts to solve the problem or in case of necessity asking teachers, parents or psychologists for support and help.

Table 3 Results on the differences of coping strategies before and after implementation of the pedagogical support program in the experimental group

\begin{tabular}{|c|c|c|c|c|c|c|}
\hline \multirow{3}{*}{ Coping strategies } & \multicolumn{6}{|c|}{ Experimental group } \\
\hline & \multicolumn{2}{|c|}{$\begin{array}{l}\text { Measurement } \\
\text { before the } \\
\text { experiment }\end{array}$} & \multicolumn{2}{|c|}{$\begin{array}{c}\text { Measurement } \\
\text { after the } \\
\text { experiment }\end{array}$} & \multirow[t]{2}{*}{$\mathbf{T}$} & \multirow[t]{2}{*}{$\mathbf{p}$} \\
\hline & $\mathbf{M}$ & SD & $\mathbf{M}$ & SD & & \\
\hline assertive action & 19,821 & 3,878 & 20,393 & 3,315 &,- 593 & ,556 \\
\hline social joining & 21,500 & 4,726 & 22,750 & 3,216 & $-2,565 *$ &, 013 \\
\hline seeking for social support & 20,929 & 6,224 & 23,750 & 3,566 & $-2,081 *$ & 042 \\
\hline cautious action & 20,071 & 3,310 & 15,107 & 4,597 & $4,637 *$ & ,000 \\
\hline instinctive action & 18,643 & 2,934 & 18,286 & 2,827 &, 464 & ,645 \\
\hline avoidant action & 17,036 & 3,554 & 13,607 & 3,614 & $3,579^{*}$ & ,001 \\
\hline indirect action & 19,929 & 3,219 & 19,179 & 3,345 &, 040 & ,968 \\
\hline antisocial action & 17,679 & 3,601 & 17,393 & 3,381 & ,306* & ,761 \\
\hline aggressive action & 17,643 & 5,704 & 13,464 & 4,940 & 2,930 &, 005 \\
\hline index of effectiveness & 1,211 & ,3968 & 1,513 & ,4017 & $-2,832 *$ & ,006 \\
\hline
\end{tabular}

Table 4 indicates that there weren't any statistically significant difference between the levels of the coping strategy after implementation of the pedagogical support program with significance level of $0.05(\mathrm{p}<0.05)$ in the control group. Most probably it was due to the fact that no training related to coping strategies took place in the control group.

Also differences in coping strategies between experimental and control groups after implementation of the pedagogical support program were researched in this study, and results are being shown in Table 5. Statistically significantly higher levels of effective, active pro-social coping strategy seeking for social support and index of effectiveness in the experimental group, 
Jūlija Maslova. The Impact of Pedagogical Support Program on Coping Strategies, Academic Achievement and Stress Level in Adolescence

were found. Statistically significant differences were found in such ineffective and passive coping strategies as cautious action, avoidant action, indirect action aggressive action that were applied by adolescents from the experimental group much less than by adolescents from the control group. The results suggest that adolescents from the experimental group are active in terms of their social interactions, while seeking their goal and trying to solve problems.

Table 4 Results on the differences of coping strategies before and after implementation of the pedagogical support program in the control group

\begin{tabular}{|c|c|c|c|c|c|c|}
\hline \multirow{3}{*}{ Coping strategies } & \multicolumn{6}{|c|}{ Control group } \\
\hline & \multicolumn{2}{|c|}{$\begin{array}{l}\text { Measurement } \\
\text { before the } \\
\text { experiment }\end{array}$} & \multicolumn{2}{|c|}{$\begin{array}{c}\text { Measurement } \\
\text { after the } \\
\text { experiment }\end{array}$} & \multirow[t]{2}{*}{$\mathbf{T}$} & \multirow[t]{2}{*}{ p } \\
\hline & $\mathbf{M}$ & SD & $\mathbf{M}$ & SD & & \\
\hline assertive action & 20,862 & 3,368 & 20,035 & 20,035 & 971 & ,336 \\
\hline social joining & 22,241 & 3,502 & 22,345 & 20,793 &,- 122 & ,904 \\
\hline seeking for social support & 20,759 & 5,125 & 2,943 & 3,922 &,- 029 & ,977 \\
\hline cautious action & 21,759 & 3,632 & 22,345 & 20,793 &,- 735 & ,466 \\
\hline instinctive action & 18,862 & 3,492 & 2,943 & 3,922 &,- 265 &, 792 \\
\hline avoidant action & 18,276 & 3,011 & 22,345 & 20,793 &, 045 & 964 \\
\hline indirect action & 21,448 & 3,470 & 2,943 & 3,922 & 280 & ,781 \\
\hline antisocial action & 19,448 & 4,835 & 22,345 & 20,793 & ,385 & ,702 \\
\hline aggressive action & 18,897 & 5,031 & 2,943 & 3,922 &,- 854 & ,397 \\
\hline index of effectiveness & 1,159 &, 227 & 22,345 & 20,793 & ,586 & ,560 \\
\hline
\end{tabular}

* $T$ - test score is significant at the $p<0.5$ level (2-tai tailed)

Table 5 Results on the differences of coping strategies between the experimental group and the control group after implementation of the pedagogical support program

\begin{tabular}{|c|c|c|r|r|r|r|}
\hline \multirow{2}{*}{ Coping strategies } & \multicolumn{5}{|c|}{ The differences of coping strategies } \\
\cline { 2 - 5 } & \multicolumn{2}{|c|}{$\begin{array}{c}\text { Experimental } \\
\text { group }\end{array}$} & \multicolumn{2}{|c|}{ Control group } & \multirow{2}{*}{ T } & \multirow{2}{*}{ p } \\
\cline { 2 - 5 } & M & \multicolumn{1}{|c|}{ SD } & \multicolumn{1}{|c|}{ M } & \multicolumn{1}{c|}{ SD } & & \\
\hline assertive action & 20,393 & 3,315 & 20,035 & 20,035 &, 420 &, 676 \\
\hline social joining & 22,750 & 3,216 & 22,345 & 20,793 &, 496 &, 622 \\
\hline seeking for social support & 23,750 & 3,566 & 2,943 & 3,922 & $2,975^{*}$ &, 004 \\
\hline cautious action & 15,107 & 4,597 & 22,345 & 20,793 & $-7,452^{*}$ &, 000 \\
\hline instinctive action & 18,286 & 2,827 & 2,943 & 3,922 &,- 977 &, 333 \\
\hline avoidant action & 13,607 & 3,614 & 22,345 & 20,793 & $-5,405^{*}$ &, 000 \\
\hline indirect action & 19,179 & 3,345 & 2,943 & 3,922 & $-2,380^{*}$ &, 021 \\
\hline antisocial action & 17,393 & 3,381 & 22,345 & 20,793 & $-1,529$ &, 132 \\
\hline aggressive action & 13,464 & 4,940 & 2,943 & 3,922 & $-5,060^{*}$ &, 000 \\
\hline index of effectiveness & 1,513 &, 4017 & 22,345 & 20,793 & $5,610^{*}$ &, 000 \\
\hline
\end{tabular}

* $T$ - test score is significant at the $p<0.5$ level (2-tailed) 
The table 6 shows that statistically significant differences have occured in GPA level of the experimental group after the pedagogical support program has been applied. The GPA level in exact sciences has increased while the one in human sciences hasn't changed. The rise of exact science GPA level could be explained with the idea that such kind of subjects requires higher attention concentration, alertness and both logical and creative approach to the problem solutions, which is difficult enough to do in a stressful situation. After applying of the pedagogical support program effective coping strategies of adolescents have been developed, as well as the stress level has been optimized, which has led to the rise of GPA level in exact science and, due to this, to the one in general.

Table 6 Results on the differences in levels of the GPA, GPA in the humanities and GPA in the exact sciencies before and after implementation of the pedagogical support program in the experimental group

\begin{tabular}{|c|c|c|c|c|c|c|}
\hline \multicolumn{7}{|c|}{ Experimental group } \\
\hline & \multicolumn{2}{|c|}{ GPA in the humanities } & \multicolumn{2}{|c|}{$\begin{array}{c}\begin{array}{c}\text { GPA in the exact } \\
\text { sciencies }\end{array} \\
\end{array}$} & \multicolumn{2}{|c|}{ GPA } \\
\hline & $\begin{array}{c}\text { before the } \\
\text { experiment }\end{array}$ & $\begin{array}{c}\text { after the } \\
\text { experime } \\
\text { nt }\end{array}$ & $\begin{array}{l}\text { before the } \\
\text { experi- } \\
\text { ment }\end{array}$ & $\begin{array}{l}\text { after the } \\
\text { experi- } \\
\text { ment }\end{array}$ & $\begin{array}{l}\text { before the } \\
\text { experi- } \\
\text { ment }\end{array}$ & $\begin{array}{l}\text { after the } \\
\text { experi- } \\
\text { ment }\end{array}$ \\
\hline $\mathrm{M}$ & 5,722 & 5,8788 & 5,6121 & 6,4449 & 5,831 & 6,373 \\
\hline SD & 1,483 & 1,12106 & ,93526 & 1,32154 & 1,778 & 1,175 \\
\hline $\mathrm{T}$ & \multicolumn{2}{|c|}{,255 } & \multicolumn{2}{|c|}{$3,958^{*}$} & \multicolumn{2}{|c|}{$2,719^{*}$} \\
\hline $\mathrm{p}$ & \multicolumn{2}{|c|}{,799 } & \multicolumn{2}{|c|}{, 000} & \multicolumn{2}{|c|}{,008 } \\
\hline
\end{tabular}

* T- test score is significant at the $p<0.5$ level (2-tailed)

The table 7 shows that there weren't any statistically significant differences in levels of the GPA, GPA in the humanities and GPA in the exact sciencies in the control group after the pedagogical support program has been applied. Table 4 indicates that there weren't any statistically significant difference between the levels of the coping strategy after implementation of the pedagogical support program with significance level of $0.05(\mathrm{p}<0.05)$ in the control group. Most probably it was due to the fact that the pedagogical support program did not take place in the control group. 
Jülija Maslova. The Impact of Pedagogical Support Program on Coping Strategies, Academic Achievement and Stress Level in Adolescence

Table 7 Results on the differences in levels of the GPA, GPA in the humanities and GPA in the exact sciencies before and after implementation of the pedagogical support program in the control group

\begin{tabular}{|c|c|c|c|c|c|c|}
\hline \multicolumn{2}{|c|}{ Control group } \\
\hline & $\begin{array}{c}\text { GPA in the humanities } \\
\text { before } \\
\text { the } \\
\text { experi- } \\
\text { ment }\end{array}$ & $\begin{array}{c}\text { GPA in the exact sciencies } \\
\text { after the } \\
\text { experi- } \\
\text { ment }\end{array}$ & $\begin{array}{c}\text { cefore the } \\
\text { experi- } \\
\text { ment }\end{array}$ & $\begin{array}{c}\text { after the } \\
\text { experi- } \\
\text { ment }\end{array}$ & $\begin{array}{c}\text { GPA } \\
\text { before the } \\
\text { exper- } \\
\text { ment }\end{array}$ & $\begin{array}{c}\text { after the } \\
\text { experi- } \\
\text { ment }\end{array}$ \\
\hline M & 5,6121 & 6,4449 & 6,0952 & 5,8566 & 5,831 & 6,133 \\
\hline SD &, 93526 & 1,32154 &, 94800 & 1,08325 &, 94640 &, 782 \\
\hline T & \multicolumn{2}{|c|}{3,958} & \multicolumn{2}{|c|}{,- 893} & \multicolumn{2}{c|}{3,958} \\
\hline $\mathrm{p}$ & \multicolumn{2}{|c|}{, 000} & \multicolumn{2}{|c|}{, 376} & \multicolumn{2}{c|}{, 000} \\
\hline
\end{tabular}

* T-test score is significant at the $p<0.5$ level (2-tailed)

\section{Conclusions}

Results of the theoretical review prove that coping strategies can be divided into effective ones, which are oriented towards problem solution and allow coping with stress situation, and ineffective - emotion-focused coping strategies, which play negative role and intensify stress, as they do not solve a situation that occurred. Coping behaviour is being realized through coping strategies, and it is grounded in personal and social environment coping resources (Малкина-Пых, 2005). Coping resources provide a possibility to carry out an optimal adaptation to stress situations.

Divergent thinking and psychological competence are the most important personal coping resources helping adolescents to cope with stressful situations. Divergent thinking facilitates development of effective coping strategies, as it allows finding solution in situations of uncertainty and lack of information. The most important social environment coping resource for adolescents is support of teachers and parents.

Grounding on results of the theoretical research work, the pedagogical support program for adolescents was elaborated and approbated. The empirical research proved hypothesis, set forward in this particular study, about the fact that the pedagogical support program allows development of effective coping strategies in adolescents; leads to reduction of stress level and increases level of academic achievement. After implementing the pedagogical support program such effective coping strategies as social joining and seeking for social support has developed and index of effectiveness, which showes the effectiveness of coping behavior in a stressful situation in the experimental group has increased. 
Also their stress level has reduced and academic achievement has improved, GPA level in general and GPA level of exact sciences in particular increased. After implementing the program no changes were determined neither in development of coping strategies nor in stress level and academic achievement in the control group.

Thus the pedagogical support program showed its efficiency and proved that it can be applied within the pedagogical process for developing effective coping strategies, optimizing stress level and improving academic achievement of adolescents.

\section{References}

Barber, I., \& Janet, E. (2010). An examination of happiness and its relationship to community college students' coping strategies. 71, 10. Baltimore: Morgan State University.

Bressler, L. A., \& Bressler, M. E. (2007). The relationship between self-esteem and selfefficacy among distance learning students in Accounting Information Systems online classes. International Journal of Innovation and Learning, 4 (3), 274-289.

Campbell, E. (2008). The influence of personality, optimism and coping strategies on academic performance, perceived stress and psychological wellbeing: a longitudinal study of first year university students. [Accessed 2015-X-X] Available at: http://hdl.handle.net/123456789/2902 (12.08.2011.)

Choi, Y. B., Abbott, T. A., Arthur, M. A., \& Hill, D. (2007). Towards a future wireless classroom paradigm. International Journal of Innovation and Learning, 4 (1), 14-25.

Compas, B. E., Connor-Smith, J. K., Saltzman, H., Thomsen, A. H., \& Wadsworth, M. E. (2001). Coping with stress during childhood and adolescence: Problems, progress and potential in theory and research. Psychological Bulletin, 127 (1), 87-128.

Fasko, D. Jr. (2011). Education and Creativity. Creativity Research Journal. Vol. 13, 3 \& 4, 317-32.

Frydenberg, E. (1997). Adolescent Coping: Theoretical and Research Perspectives. London: Routledge.

Frydenberg, E. (2002). Beyond Coping. Meeting goals, visions and challenges. Oxford: Oxford University Press.

Guilford, J. P. (1985). The structure-of-intellect model. Handbook of intelligence: Theories, measurements, and applications. Wolman, B. B. (Ed.), 225-266. New York: Wiley.

Hofer, M. (2007). Goal conflict and self-regulations: A new look at pupils' off-task behaviour in the classroom. Educational Research Review, 2 (1), 28-38.

Hobfoll, S. E., Dunahoo, C. L., Monnier, J., Hulsizer, M. R., \& Johnson, R. (1998). There's more than rugged individualism in coping. Part 1: Even the Lone Rangerhad Tonto. Anxiety, Stress, Coping: An International Journal, 11 (2), 137-65.

Kaplan, H. I., \& Saddock, B. J. (2000). Learning theory, in: Sypnosis of Psychiatry: Behavioral Sciences/Clinical Psychiatry. 8th edn, 148-154. Philadelphia: Lippincott. Williams \& Wilkins.

Laio, K., Lu, J., \& Yi, Y. (2007). Research on humanized web-based learning model. International Journal of Innovation and Learning, 4 (2), 186-196.

Lazarus, R. S., \& Folkman, S. (1984). Stress, appraisal and coping. New York: Springer Publishing Company. 
Jūlija Maslova. The Impact of Pedagogical Support Program on Coping Strategies, Academic Achievement and Stress Level in Adolescence

Latviešu valodas skaidrojošā vārdnīca. D. Guḷevskas red. (1987). Rīga: Avots.

Marcos, J. J. M., \& Tillema, H. (2006). Studying studies on teacher reflection and action: An appraisal of research contribution. Educational Research Review, 1 (2), 112-132.

Maslova, J. (2016). Development of coping strategies in adolescents in pedagogical process. Teacher Education. Šiauliai: Šiauliai University (in press)

Monnier, J., Hobfoll, S. E., Dunahoo, C. L., Hulsizer, M. R., \& Johnson, R. (1998). There's more than rugged individualism in coping. Part 2: Construct validity and further model testing. Anxiety, Stress, Coping: An International Journal, 11 (3), 247-272.

Niff, K., Hsieh, Y. P., \& Dejitterat, K. (2005). Self-compassion, achievement goals, and coping with academic failure. Self and Identity, 4. 263-287. Oxford: Psychology Press: Taylor \& Francis Group.

Rafidah, K., Azizah, A., Norzaidi, M., Chong. S., Salwani, M., \& Noraini, I. (2009-01-01). Stress and academic performance: empirical evidence from university students. Academy of Educational Leadership Journal Source, 13 (1) Available at: http://www.freepatentsonline.com/article/Academy-Educational-LeadershipJournal/208747713.html

Rutka, L. (2012). Pedagoga psihologiskā kompetence. Rīga: RaKa

Selje, H. (2012). Mana mūža stress: zinātnieka memuāri. Rīga: Jumava.

Smith, T., \& Renk, K. (2007). Predictors of academic-related stress in college students: an coping, social support, parenting, and anxiety. NASPA Journal, 44, (3), 405-431.

Tucker, H. F. (2008). The influence of optimism above personality and coping on academic performance, wellbeing and perceived stress during a major life transition. [Accessed 2011-10-19] Available: http://www.era-test.lib. ed.ac.uk/handle/123456789/2902

Veisson, M., Leino, M., Ots, L., Ruus, V. R., \& Sarv, E. S. (2004). Academic coping of students. Paper presented at the European Conference on Educational Research, University of Crete, 22-25 September, 2004. Crete: University of Crete.

Velika, B., Pudule, I., Grinberga, D. Gobina, I., Tilgale, N., Villeruša, A., \& Teibe, U. (2008). Veselība un psihoemocionālā labklājība skolas vecuma bērniem Latvijāa. Rīga: „Sabiedrības veselības aǵentūra”.

Yusoff, M., Ahmad Hamid, A., Rosli, N., Zakaria, N., Che Rameli, N., Abdul Rahman, N., Abdul Rahim, A., \& Abdul Rahman, A. (2010-12-01). Prevalence of stress, stressors and coping strategies among secondary school students in Kota Bharu, Kelantan, Malaysia. International Journal of Students' Research. [Accessed: 2012-02-22] Available at: http://www.ijsronline.com/index.php/IJSR/article/view/19/217

Амонашвили, Ш. А. (1995). Размылиления о гуманной педагогике. Москва: Издательский Дом Шалвы Амонашвили.

Водопьянова, Н. Е. (2009). Психодиагностика стресса. СПб: Питер

Газман, О. С. (1995). Педагогическая поддержка детей в образовании как инновационная проблема. Новые ценности образования: десять концепций и эссе. Москва: Инноватор

Грецов, А. (2012). Тренинги развития с подростками: творчество, общение, самопознание. Санкт-Петербург: Питер

Ильин, Е. П (2012). Психология творчества, креативности, одаренности. СанктПетербург: Питер

Колиенко, Н. С. (2008). Роль творческих способностей в выборе копинг-стратегий у подростков. Седьмая волна психологии. Вып. 3./ Сб. под ред. Козлова, В. В., Качановой, Н. А. Ярославль, Минск: МАПН, ЯрГУ. 
Крюкова, Т (2010). Методы изучения совладающего поведения: три копинг шкаль Кострома: «Авантитул»

Малкина-Пых, И. Г. (2005). Психосоматика: Справочник практического психолога. Москва: Эксмо.

Останина, Н (2009). Педагогическая поддержка поведения подростков по преодолению трудных школьных ситуаций. Автореферат диссертации кандидата педагогических наук. Смоленск: Смоленский государственный университет.

Рассказова, Е. И., \& Гордеева, Т. О. (2011). Копинг-стратегии в психологии стресса: подходы, методы и перспективы исследований. Психологические исследования, 3 (17). (дата обращения: 12.11.2011.) Доступно: http://psystudy.ru 